\title{
FAKTOR-FAKTOR YANG MEMPENGARUHI PEMILIHAN BANK PADA GENERASI MILENIAL DI JABODETABEK
}

\author{
Anindia Indah Permata ${ }^{1}$, Martinus Rosadi Nugroho ${ }^{2}$, \\ Elias Sugita Handoyo ${ }^{3}$, Ivan Angga Kusuma ${ }^{4}$ \\ ${ }^{1}$ anindiaindah@yahoo.com \\ ${ }^{2}$ martinus.rosadi@gmail.com \\ 3 elias.sugitahandoyo@yahoo.com \\ 4ivan.ak54@yahoo.com
}

Program MM Sekolah Bisnis dan Ekonomi Universitas Prasetiya Mulya

\begin{abstract}
This paper aim to determine factors that influence millennials generation at Jabodetabek in selecting a bank for their financial transaction. The significance level on banking selection criteria such as people influence, location, facilities offered, bank personnel, easiness in process, quality of services, and cost were also being researched. This study describes how customer rank these factors by their priorities. Total sample of this study are 224 samples from millennials generation (born during 1980-2000) domiciled at Jakarta, Bogor, Depok, Tangerang, and Bekasi (Jabodetabek). This study finds that convenient ATM location is the main factor for millennials at Jabodetabek in selecting a bank for their financial transaction.
\end{abstract}

Keywords: bank selection criteria, service quality, millennials, Indonesia, banking

\section{SARI PATI}

Penelitian ini bertujuan untuk mengetahui faktor-faktor yang mempengaruhi pemilihan bank pada generasi milenial di Jabodetabek dalam melakukan transaksi keuangan. Tingkat signifikansi kriteria pemilihan Bank seperti pengaruh orang lain, fasilitas, lokasi, karyawan Bank, kemudahan memperoleh pinjaman, kualitas layanan, dan biaya juga diteliti dalam penelitian ini. Penelitian ini menjelaskan bagaimana konsumen memberikan peringkat terhadap faktor-faktor tersebut berdasarkan prioritas mereka. Total sampel penelitian adalah 224 orang yang tergolong ke dalam generasi milenial (kelahiran tahun 1980-2000) dan berdomisili di Jakarta, Bogor, Depok, Tangerang, dan Bekasi (Jabodetabek). Ditemukan bahwa lokasi ATM yang mudah dijangkau menjadi faktor utama dalam pemilihan Bank bagi generasi milenial di Jabodetabek dalam melakukan transaksi keuangan.

\section{PENDAHULUAN}

Di era teknologi informasi saat ini, kondisi persaingan usaha meningkat di hampir setiap sektor. Begitu pula halnya di dalam sektor perbankan, bank harus bekerja keras untuk memenuhi ekspektasi dari konsumen. Manajemen bank lokal pun kini harus menghadapi persaingan dengan bank asing, dimana kreatifitas manajemen dalam mengakomodir seluruh kebutuhan konsumen merupakan satu hal yang penting untuk dilakukan. Semakin ketatnya persaingan di dunia perbankan menjadikan setiap pembuat strategi pemasaran memiliki peranan penting di dalam identifikasi dan pengembangan 
strategi untuk sebuah bank (Sadiq et.al 2014). Hanya bank yang mampu menarik konsumen baru dan mempertahankan konsumen lama yang mungkin dapat tumbuh dan berkembang untuk periode yang lama (Sadiq et.al 2014).

Perubahan kondisi pasar perbankan yang sangat cepat membuat bank harus menyesuaikan kembali strategi pemasarannya, dimulai dari hanya berfokus pada konsumen korporasi (customer corporate) dan sektor komersial, menjadi turut memperhatikan segmen retail, konsumen individu, serta sektor usaha kecil dan menengah (SME). Hal ini didukung oleh meningkatnya tren pendirian start-up atau perusahaan baru berbasis teknologi dengan ukuran mikro sampai menengah. Start-up baru yang banyak bermunculan nyatanya menjadi suatu tren baru di kalangan generasi milenial, khususnya di Jabodetabek. Tidak hanya pada perusahaan berbasis teknologi, adapun tren entrepreneurial juga merambah di berbagai sektor lainnya. Dikutip dari Situs CNN Indonesia (2017), Biro Pusat Statistik (BPS) mencatat jumlah usaha menurut hasil sementara pendaftaran usaha Sensus Ekonomi (SE) 2016 sebanyak 26,7 juta wirausahawan non-pertanian atau naik sekitar 17,6 persen dari tahun 2006.

Dengan jumlah generasi milenial sejumlah 85 juta jiwa atau mencapai 34,45\% dari total seluruh penduduk Indonesia, generasi milenial merupakan pasar yang memiliki potensi besar di tengah industri perbankan (Situs Bisnis Indonesia, 2017). Dilansir dari Situs Kontan, bahwa generasi ini akan mendominasi perekonomian di Indonesia sampai dengan jagka waktu 30 tahun mendatang. Adapun perbedaan karaktertistik seperti pola pikir, mobilitas yang tinggi, kecenderungan kurang penyabar, dan jiwa petualang merupakan satu hal yang membedakan generasi milenial dengan generasi sebelumnya. $\mathrm{Hal}$ ini pun turut dipengaruhi oleh penggunaan teknologi semenjak usia dini dan juga efek globalisasi (Situs Kontan, 2017). Sehingga, berkaca dari karakteristik generasi milenial tersebut maka dapat dikatakan bahwa generasi ini memerlukan layanan perbankan yang cepat dan efisien untuk dapat menyesuaikan kegiatan keseharian mereka.

Bank dituntut untuk menangkap peluang baru dari sektor yang masih hijau ini. Namun untuk dapat melihat peluang yang ada, bank memerlukan informasi mengenai ekspektasi generasi milenial terhadap layanan perbankan. Tidak dipungkiri bahwa inti dari bisnis perbankan adalah selalu berpegang pada asas kepercayaan, sehingga kualitas layanan menjadi satu kriteria penting yang menjadi dasar pertimbangan nasabah atau konsumen dalam memilih sebuah bank. Reputasi bank menjadi faktor yang krusial dalam memilih bank di beberapa negara karena asas kepercayaan tersebut (Almossawi 2001).

Namun hal ini tidak dapat dijadikan tolak ukur yang sama di seluruh dunia, dimana penelitian yang dilakukan pada suatu negara tidak serta merta menjadikan penelitian tersebut berlaku sama di negara lainnya. Begitu pula halnya pada penelitian terkait faktor-faktor pemilihan bank yang terbukti memberikan hasil berbeda pada beberapa negara tempat dilakukannya penelitian. Adanya perbedaan kondisi sosial, ekonomi, politik, dan budaya menimbulkan perbedaan persepsi masyarakat terhadap kriteriakriteria pemilihan sebuah bank. Oleh karena itu, maka perlu dilakukan studi secara lebih mendalam untuk dapat menentukan faktor-faktor yang dianggap penting oleh golongan masyarakat di suatu Negara ataupun wilayah tertentu. 
Penelitian ini bertujuan untuk menyediakan informasi terkait ekspekatasi dan kebutuhan dari generasi milenial terhadap layanan perbankan. Dimana faktor-faktor yang menjadi bahan pertimbangan ketika memilih layanan perbankan dalam melakukan transaksi keuangan tersebut akan diurutkan berdasarkan tingkat prioritasnya oleh generasi milenial di wilayah Jabodetabek. Keterbatasan waktu dan sumberdaya menjadikan penelitian ini berfokus hanya pada jangkauan area Jabodetabek.

\section{TINJAUAN PUSTAKA DAN PENGEMBANGAN HIPOTESIS}

Menurut UU no. 10 tahun 1998 tentang Perbankan, Bank adalah badan usaha yang menghimpun dana dari masyarakat dalam bentuk simpanan dan menyalurkannya kepada masyarakat dalam bentuk kredit dan atau bentuk-bentuk lainnya dalam rangka meningkatkan taraf hidup masyarakat. Lebih jauh, bank umum adalah bank yang melaksanakan kegiatan usaha secara konvensional dan atau berdasarkan prinsip syariah, yang dalam kegiatannya memberikan jasa dalam lalu lintas pembayaran.

Beberapa penelitian terdahulu yang membahas topik serupa antara lain - di Malaysia (Sadiq et.al 2014), India (Srivatsa \& Srinivasan 2008), Bahrain (Almossawi 2001), USA, Taiwan, \& Ghana (Blankson et.al 2007), UAE (Sayani \& Miniaoui 2013), Afrika Selatan (Coetzee et.al 2012), Rumania (Katircioglu et.al 2011). Masing-masing negara memiliki faktor utamanya masing-masing. Perbedaan keadaan ekonomi, politik, dan budaya mempengaruhi faktor utama pemilihan bank di setiap negara. Penelitian dari Martenson di tahun 1985 menemukan bahwa responden berusia muda masih dipengaruhi oleh orang tua dalam memilih bank. Penelitian di Bahrain yang dilakukan oleh Almossawi (2001) menjelaskan bahwa faktor kunci bagi mahasiswa di Bahrain dalam memilih bank adalah reputasi bank, ketersediaan lahan parkir, karyawan bank yang bersahabat, dan ketersediaan serta lokasi ATM yang mudah dijangkau. Selain itu, terdapat juga negara yang menemukan bahwa faktor teknologi seperti ATM dan internet banking menjadi kriteria utama dalam memilih bank (Rao \& Sharma 2010, Musiime \& Ramadhan 2011, Daude \& Akingbade 2011, dan Aregbeyen 2011). Sementara Manrai et.al di tahun 2007 menemukan bahwa keramahan karyawan bank menjadi faktor paling penting dalam pemilihan sebuah bank.

Terdapat 28 kriteria dalam pemilihan bank oleh konsumen (Sadiq et.al.,2014), antara lain: "layanan bank cepat dan efisien", "kemudahan nasabah membuka rekening baru", "biaya administrasi rendah", "sikap hormat karyawan bank", "lokasi ATM", "lokasi bank dekat rumah atau kantor", "kesedian karyawan bank membantu nasabah", " suku bunga tabungan tinggi", "suku bunga pinjaman rendah", "ketersediaan lahan parkir", "ketersediaan desain kartu kredit/debit", "ketersediaan layanan konsultasi keuangan", "kualitas customer services", "keakuratan transaksi perbankan", "kemudahan pinjaman bank", "jam operasional bank", "profesionalitas manajer", "iklan pada media masa", "biaya administrasi bersaing", "ketersediaan informasi produk dan layanan perbankan", "ketersediaan internet banking", "kompetensi dan pengetahuan staff", "resepsionis ramah", "variasi produk beragam", "ketersediaan telephone banking", "reputasi yang baik", "rekomendasi saudara dan keluarga", dan "rekomendasi teman". Ke-28 kriteria ini menjadi acuan bagi peneliti untuk mengetahui faktor-faktor yang mempengaruhi 
pemilihan bank pada generasi milenial di Jabodetabek dalam melakukan transaksi keuangan.

Menurut publikasi yang diterbitkan Pricewaterhouse Coopers di tahun 2011, seseorang dikategorikan sebagai generasi milenial apabila ia lahir di antara periode 1980 sampai 2000. Sementara Howe dan Strauss (2003) menyebutkan bahwa generasi milenial adalah orang-orang yang lahir di antara tahun 1981 sampai tahun 2000. Senada dengan Howe dan Strauss, Cooper (2012) juga sependapat melalui publikasi dari National Chamber Foundation (NCF), sebuah yayasan afiliasi dari U.S. Chamber of Commerce, bahwa generasi milenial merupakan orang-orang yang lahir antara tahun 1981-2000. Banyaknya variasi rentang periode membuat peneliti memilih untuk menggunakan rentang periode yang paling besar yakni antara tahun 1980 hingga 2000.

\section{METODOLOGI PENELITIAN}

Penelitian ini bersifat hybrid, penelitian dilakukan secara kualitatif dan kuantitatif. Secara kualitatif, peneliti melakukan wawancara kepada 20 narasumber untuk mengetahui apakah terdapat faktor-faktor diluar dari ke-28 faktor yang terdapat pada penelitian sebelumnya. Kemudian, metode kuantitatif disajikan ke dalam penelitian dengan pengumpulan data primer menggunakan pengisian responden melalui sebaran kuesioner sebagai media pengumpul data. Terlebih dahulu peneliti menyebarkan pretest kuesioner pada 10 responden, untuk mengetahui apakah terdapat kesulitan bagi responden untuk memahami dan melakukan pengisian. Adapun pada awal penelitian ditargetkan sejumlah 300 responden, sebab jumlah tersebut diperkirakan cukup representatif untuk memperoleh kesimpulan yang valid pada metode faktor analisis (Field 2005).

Adapun metode sampling yang dilakukan adalah purposive sampling dengan memberikan kesempatan yang sama pada relasi dari peniliti untuk melakukan pengisian kuesioner. Kuesioner dengan platform Google Form dibagikan melalui aplikasi smartphone dan juga media sosial, sehingga responden dapat mengisi kuesioner tersebut dari ponsel ataupun komputer. Kuesioner dibagikan semenjak 20 Juli 2017 dengan kurun waktu 14 hari. Untuk pengolahan data, digunakan software IBM SPSS Statistics versi 23.

\section{HASIL PENELITIAN DAN ANALISIS}

Dari hasil wawancara kepada 20 narasumber, tidak ditemukan adanya faktor tambahan dalam pemilihan layanan perbankan, sehingga penelitian dapat dilanjutkan dengan menggunakan ke-28 faktor yang ada (hasil wawancara terlampir). Kemudian, pada pretest kuesioner pada 10 responden, diketahui bahwa ke-10 responden tidak menemukan kesulitan dalam memahami dan melakukan pengisian, sehingga kuesioner dianggap layak untuk dijadikan kuesioner penelitian.

Dari ke-236 data kuesioner yang telah melakukan pengisian kuesioner sampai dengan tanggal 2 Agustus 2017, sebanyak 12 data dinyatakan tidak valid karena responden berada di luar jangkauan usia generasi milenial dan beberapa responden tidak berdomisili di area Jabodetabek. Maka dari itu, data valid yang berhasil dikumpulkan melalui sebaran kuesioner berjumlah 224 data. 
Tabel 1. Karkteristik Responden

\begin{tabular}{|c|c|c|}
\hline Karakteristik Responden & Jumlah $(n=224)$ & Persentase \\
\hline \multicolumn{3}{|l|}{ Gender } \\
\hline Pria & 117 & $52,23 \%$ \\
\hline Wanita & 107 & $47,77 \%$ \\
\hline \multicolumn{3}{|l|}{ Umur } \\
\hline$<17$ tahun & 0 & $0,00 \%$ \\
\hline 18-22 tahun & 26 & $11,61 \%$ \\
\hline 23-27 tahun & 150 & $66,96 \%$ \\
\hline 28-32 tahun & 40 & $17,86 \%$ \\
\hline 33-37 tahun & 8 & $3,57 \%$ \\
\hline$>38$ tahun & 0 & $0,00 \%$ \\
\hline \multicolumn{3}{|l|}{ Pekerjaan } \\
\hline Pelajar/mahasiswa & 35 & $15,63 \%$ \\
\hline Karyawan Swasta & 138 & $61,61 \%$ \\
\hline Pegawai Negeri & 8 & $3,57 \%$ \\
\hline Wirausaha & 25 & $11,16 \%$ \\
\hline Profesional & 17 & $7,59 \%$ \\
\hline Lainnya & 1 & $0,45 \%$ \\
\hline \multicolumn{3}{|l|}{ Domisili } \\
\hline Jakarta & 122 & $54,46 \%$ \\
\hline Bogor & 10 & $4,46 \%$ \\
\hline Depok & 17 & $7,59 \%$ \\
\hline Tangerang & 32 & $14,29 \%$ \\
\hline Bekasi & 43 & $19,20 \%$ \\
\hline \multicolumn{3}{|l|}{ Pendidikan terakhir } \\
\hline SMP & 0 & $0,00 \%$ \\
\hline SMA & 25 & $11,16 \%$ \\
\hline S1 & 180 & $80,36 \%$ \\
\hline S2 & 11 & $4,91 \%$ \\
\hline S3 & 0 & $0,00 \%$ \\
\hline lainnya & 8 & $3,57 \%$ \\
\hline \multicolumn{3}{|l|}{ Status perkawinan } \\
\hline Menikah & 38 & $16,96 \%$ \\
\hline Belum menikah & 186 & $83,04 \%$ \\
\hline \multicolumn{3}{|l|}{ Jumlah rekening bank } \\
\hline 1 & 40 & $17,86 \%$ \\
\hline 2 & 98 & $43,75 \%$ \\
\hline 3 & 49 & $21,88 \%$ \\
\hline 4 & 23 & $10,27 \%$ \\
\hline$>5$ & 14 & $6,25 \%$ \\
\hline
\end{tabular}

Sumber: SPSS Penelitian 
Dari sisi jenis kelamin, sebaran responden terbagi cukup merata. Terlihat pada Tabel.1, terdapat 117 responden pria dan 107 responden wanita. Sementara, mayoritas responden berusia di kisaran 23-27 tahun. Hal ini terlihat dari persentase responden umur 23-27 tahun yang mencapai 66,96\% dari total responden. Mayoritas responden bekerja sebagai karyawan swasta dengan persentase $61,61 \%$ dari total responden. Kemudian, mayoritas responden berdomisili di Jakarta $(54,46 \%)$ serta memiliki pendidikan terakhir di tingkat S1 (80,36\%). Adapun $83,04 \%$ responden penelitian belum menikah dan mayoritas memiliki 2 rekening tabungan pada bank $(43,75 \%)$.

Tabel 2. Statistik Deskriptif

Descriptive Statistics

\begin{tabular}{|c|c|c|c|c|}
\hline No. & Items & Mean & \begin{tabular}{|c|} 
Std. \\
Deviation
\end{tabular} & Rank \\
\hline 1 & Lokasi ATM yang mudah dijangkau. & 6,683 & 0,7103 & 1 \\
\hline 2 & Layanan bank yang cepat dan efisien. & 6,674 & 0,6109 & 2 \\
\hline 3 & Reputasi bank yang baik. & 6,634 & 0,6352 & 3 \\
\hline 4 & Ketersediaan layanan Internet Banking. & 6,545 & 0,8023 & 4 \\
\hline 5 & Keakuratan layanan transaksi perbankan. & 6,531 & 0,6887 & 5 \\
\hline 6 & Biaya administrasi bulanan yang rendah. & 6,478 & 0,9655 & 6 \\
\hline 7 & Kesediaan karyawan bank dalam membantu nasabah. & 6,438 & 0,8340 & 7 \\
\hline 8 & Kualitas customer services yang baik. & 6,411 & 0,7873 & 8 \\
\hline 9 & Kemudahan nasabah dalam membuka rekening baru. & 6,321 & 0,9678 & 9 \\
\hline 10 & Staff yang kompeten dan memiliki pengetahuan luas. & 6,268 & 0,9702 & 10 \\
\hline 11 & Sikap hormat dari karyawan bank. & 6,237 & 1,0427 & 11 \\
\hline 12 & Lokasi bank dekat dengan rumah ataupun tempat kerja. & 6,210 & 1,0654 & 12 \\
\hline 13 & Manager bank yang profesional dan dapat dipercaya. & 6,071 & 1,2791 & 13 \\
\hline 14 & Resepsionis (security bank) yang ramah. & 5,987 & 1,1344 & 14 \\
\hline 15 & Tingkat suku bunga pinjaman yang rendah. & 5,920 & 1,3700 & 15 \\
\hline 16 & Tingkat suku bunga tabungan yang tinggi. & 5,839 & 1,5708 & 16 \\
\hline 17 & Jam operasional bank. & 5,795 & 1,4183 & 17 \\
\hline 18 & Kemudahan nasabah dalam memperoleh pinjaman. & 5,786 & 1,1974 & 18 \\
\hline 19 & Biaya administrasi yang ditawarkan bersaing. & 5,732 & 1,2775 & 19 \\
\hline 20 & Ketersediaan informasi mengenai produk dan layanan terbaru di bank. & 5,661 & 1,3530 & 20 \\
\hline 21 & Ketersediaan telephone banking. & 5,567 & 1,5019 & 21 \\
\hline 22 & Bank menyediakan layanan konsultasi keuangan. & 5,518 & 1,2127 & 22 \\
\hline 23 & Variasi produk yang ditawarkan beragam. & 5,469 & 1,2702 & 23 \\
\hline 24 & Ketersediaan lahan parkir di bank. & 5,330 & 1,4542 & 24 \\
\hline 25 & Rekomendasi dari saudara/keluarga. & 5,268 & 1,3657 & 25 \\
\hline 26 & Rekomendasi dari teman. & 5,165 & 1,3441 & 26 \\
\hline 27 & Ketersediaan dan desain kartu kredit/debit. & 4,871 & 1,5836 & 27 \\
\hline 28 & Iklan bank ditanyangkan pada media masa. & 4,455 & 1,5264 & 28 \\
\hline
\end{tabular}

Sumber: SPSS Penelitian

Dari temuan didapatkan bahwa ke-5 faktor pemilihan bank terpenting bagi generasi milenial di Jabodetabek adalah: "lokasi ATM yang mudah dijangkau" $(6,68)$, "layanan bank yang cepat dan efisien" $(6,67)$, "reputasi bank yang baik" $(6,63)$, "ketersediaan layanan internet banking" (6,54), dan "keakuratan layanan transaksi perbankan" $(6,53)$. Setelah melihat statistik deskriptif dari faktor-faktor yang ada, peneliti melakukan uji KMO atau Kaiser Meyer Olkin Measure of Sampling. KMO adalah uji yang mengukur kecukupan sampling yang sudah dilakukan, dimana sampling dianggap mencukupi jika nilai KMO lebih dari 0,5 (Field 2005). Hasil penelitian menunjukkan bahwa nilai KMO 
adalah sebesar 0,888 - dengan demikian sampling yang dilakukan telah memenuhi persyaratan karena memiliki nilai di atas 0,5 . Selain $\mathrm{KMO}$, terdapat uji lain yang diperlukan untuk memeriksa apakah faktor-faktor tersebut memiliki pengaruh yang signifikan terhadap tujuan penelitian, yaitu Bartlett Test of Sphericity. Hasil perhitungan menggunakan SPSS menunjukkan bahwa nilai Barlett Test of Spehricity adalah sebesar 3032,464 dengan signifikansi sebesar 0,000. Dengan demikian Bartlett Test of Spehricity memenuhi persyaratan, karena signifikansi data penelitian di bawah 0,05 (5\%). Berikut hasil uji KMO dan Bartlett dari penelitian ini pada Tabel 3.

Tabel 3. Uji KMO dan Bartlett

KMO and Bartlett's Test

\begin{tabular}{|c|c|c|}
\hline $\begin{array}{l}\text { Kaiser-Meyer-Olk } \\
\text { Adequacy. } \\
\text { Bartlett's Test of } \\
\text { Sphericity }\end{array}$ & $\begin{array}{l}\text { sure of Sampling } \\
\text { Approx. Chi-Square } \\
\text { df } \\
\text { Sig. }\end{array}$ & $\begin{array}{r}.888 \\
3032.464 \\
378 \\
.000\end{array}$ \\
\hline
\end{tabular}

Sumber : Olahan data SPSS Penelitian

Setelah melakukan uji KMO, peneliti melakukan uji anti-image correlation yang juga digunakan untuk menguji kecukupan sampling. Dari hasil uji anti-image correlation, seluruh variabel memiliki nilai Measures of Sampling Adequacy (MSA) di atas 0,5 sehingga seluruh variabel dianggap memenuhi kecukupan sampling dan tidak terdapat variabel yang perlu dibuang (Hidayat 2014). Setelah seluruh variabel diuji, ke-28 variabel tersebut layak dan valid untuk dianalisis.

Proses selanjutnya adalah dimension reduction. Tujuan dari proses ini adalah untuk mengelompokkan ke-28 variabel tersebut ke dalam kriteria-kriteria baru berdasarkan kesamaan sifat. Proses dimension reduction tersebut dilakukan melalui program SPSS dan didapat hasil sebagai berikut:

Tabel 4. Hasil Dimension Reduction menggunakan SPSS 


\begin{tabular}{|c|c|c|c|c|c|c|c|c|c|}
\hline \multirow[b]{2}{*}{ Component } & \multicolumn{3}{|c|}{ Initial Eigenvalues } & \multicolumn{3}{|c|}{ Extraction Sums of Squared Loadings } & \multicolumn{3}{|c|}{ Rotation Sums of Squared Loadings } \\
\hline & Total & $\%$ of Variance & Cumulative \% & Total & \% of Variance & Cumulative \% & Total & \% of Variance & Cumulative \% \\
\hline 1 & 9.433 & 33.690 & 33.690 & 9.433 & 33.690 & 33.690 & 5.476 & 19.556 & 19.556 \\
\hline 2 & 2.107 & 7.524 & 41.214 & 2.107 & 7.524 & 41.214 & 2.777 & 9.918 & 29.474 \\
\hline 3 & 1.647 & 5.881 & 47.096 & 1.647 & 5.881 & 47.096 & 2.336 & 8.344 & 37.818 \\
\hline 4 & 1.455 & 5.195 & 52.291 & 1.455 & 5.195 & 52.291 & 2.007 & 7.167 & 44.985 \\
\hline 5 & 1.282 & 4.580 & 56.871 & 1.282 & 4.580 & 56.871 & 1.980 & 7.070 & 52.055 \\
\hline 6 & 1.206 & 4.307 & 61.178 & 1.206 & 4.307 & 61.178 & 1.898 & 6.778 & 58.833 \\
\hline 7 & 1.066 & 3.807 & 64.985 & 1.066 & 3.807 & 64.985 & 1.722 & 6.152 & 64.985 \\
\hline 8 & .960 & 3.428 & 68.413 & & & & & & \\
\hline 9 & .849 & 3.032 & 71.445 & & & & & & \\
\hline 10 & .781 & 2.788 & 74.233 & & & & & & \\
\hline 11 & .701 & 2.502 & 76.736 & & & & & & \\
\hline 12 & .664 & 2.371 & 79.107 & & & & & & \\
\hline 13 & .634 & 2.265 & 81.372 & & & & & & \\
\hline 14 & .591 & 2.112 & 83.483 & & & & & & \\
\hline 15 & .532 & 1.900 & 85.384 & & & & & & \\
\hline 16 & .484 & 1.727 & 87.111 & & & & & & \\
\hline 17 & .454 & 1.622 & 88.733 & & & & & & \\
\hline 18 & .413 & 1.475 & 90.208 & & & & & & \\
\hline 19 & .391 & 1.398 & 91.605 & & & & & & \\
\hline 20 & .373 & 1.333 & 92.938 & & & & & & \\
\hline 21 & .338 & 1.208 & 94.146 & & & & & & \\
\hline 22 & .320 & 1.144 & 95.290 & & & & & & \\
\hline 23 & .279 & .996 & 96.286 & & & & & & \\
\hline 24 & .270 & .965 & 97.251 & & & & & & \\
\hline 25 & .231 & .825 & 98.076 & & & & & & \\
\hline 26 & .214 & .765 & 98.841 & & & & & & \\
\hline 27 & .175 & .625 & 99.466 & & & & & & \\
\hline 28 & .150 & .534 & 100.000 & & & & & & \\
\hline
\end{tabular}

\section{Sumber: SPSS Penelitian}

Dapat diamati pada tabel 4, kriteria baru dapat dikategorikan apabila faktor memiliki total nilai eigenvalues di atas 1 . Dari ke-28 faktor awal, terdapat 7 faktor yang memiliki nilai eigenvalues di atas 1 , sehingga terbentuk 7 kriteria baru yang dapat mewakili ke-28 faktor awal. Pada tabel terlihat bahwa faktor 1 mewakili 33,690\% dari keseluruhan varians, sementara faktor 2 mewakili 7,524\% total varians, faktor 3 mewakili 5,881\% total varians, faktor 4 mewakili 5,195\% total varians, faktor 5 mewakili 4,580\% total varians, faktor 6 mewakili 4,307\% total varians, dan faktor 7 mewakili sebanyak 3,807\% varians dimana secara total ke 7 kriteria baru mewakili $64,985 \%$ total varians.

Kemudian untuk menentukan letak faktor-faktor awal setelah proses dimension reduction, dapat ditemukan pada Tabel.5 menggunakan Rotated Component Matrix yang diperoleh melalui program SPSS. Di dalam tabel, ke-28 faktor awal sudah diurutkan ke dalam masing-masing kategori faktor baru. Pada tabel Rotated Component Matrix dari setiap faktor awal dicari dan dikelompokan faktor-faktor berdasarkan nilai yang terbesar diantara faktor tersebut. Sebagai contoh, untuk faktor pada baris pertama yaitu "Ketersediaan informasi mengenai produk dan layanan terbaru di bank", nilai terbesar terdapat pada kolom 1, sehingga faktor tersebut berada di dalam 1 dari 7 faktor baru yang dihasilkan oleh proses dimension reduction. Dari Tabel.5 dapat dilihat letak posisi faktor awal di dalam faktor yang baru.

Berikut penamaan ke-7 faktor baru yang mewakilkan ke-28 faktor awal:

Faktor 1: Keramahan dan kompetensi staf bank (terdiri dari faktor 4, 7, 12, 16, $17,18,20,22,23,24,25)$

Faktor 2: Kualitas layanan yang ditawarkan (terdiri dari faktor 1, 13, 14, 21, 26) 
Faktor 3: Fasilitas yang ditawarkan (terdiri dari faktor 10 \& 11)

Faktor 4: Pengaruh orang lain (terdiri dari faktor 27 \&28)

Faktor 5: Kemudahan memperoleh pinjaman (terdiri dari faktor 2, 9, 15)

Faktor 6: Lokasi (terdiri dari faktor 5 \& 6)

Faktor 7: Biaya (terdiri dari faktor 3, 8, 19)

Tabel 5. Rotated Component Matrix

\begin{tabular}{|c|c|c|c|c|c|c|c|}
\hline & \multicolumn{7}{|c|}{ Component } \\
\hline & 1 & 2 & 3 & 4 & 5 & 6 & 7 \\
\hline $\begin{array}{l}\text { Ketersediaan informasi } \\
\text { mengenai produk dan } \\
\text { layanan terbaru di bank. }\end{array}$ & .765 & .010 & .042 & .079 & .141 & .135 & .216 \\
\hline $\begin{array}{l}\text { Variasi produk yang } \\
\text { ditawarkan beragam. }\end{array}$ & .731 & .057 & .046 & .210 & .136 & .038 & .178 \\
\hline Jam operasional bank. & .715 & .154 & .237 & .086 & .169 & .199 & -.056 \\
\hline $\begin{array}{l}\text { Staff yang kompeten dan } \\
\text { memiliki pengetahuan } \\
\text { luas. }\end{array}$ & .699 & .424 & .203 & -.060 & .170 & .029 & -.017 \\
\hline $\begin{array}{l}\text { Manager bank yang } \\
\text { profesional dan dapat } \\
\text { dipercaya. }\end{array}$ & .688 & .327 & .170 & -.064 & .179 & .136 & -.065 \\
\hline $\begin{array}{l}\text { Ketersediaan telephone } \\
\text { banking. }\end{array}$ & .669 & .133 & -.002 & .285 & .085 & .044 & .090 \\
\hline $\begin{array}{l}\text { Iklan bank ditanyangkan } \\
\text { pada media masa. }\end{array}$ & .561 & -.185 & .403 & .190 & -.112 & .126 & .324 \\
\hline $\begin{array}{l}\text { Kesediaan karyawan } \\
\text { bank dalam membantu } \\
\text { nasabah. }\end{array}$ & .534 & .302 & .291 & .086 & .248 & .099 & 102 \\
\hline $\begin{array}{l}\text { Bank menyediakan } \\
\text { layanan konsultasi } \\
\text { keuangan. }\end{array}$ & .517 & .032 & .362 & .068 & -.015 & .080 & .337 \\
\hline $\begin{array}{l}\text { Resepsionis (security } \\
\text { bank) yang ramah. }\end{array}$ & .502 & .365 & .485 & .102 & .072 & .125 & .016 \\
\hline $\begin{array}{l}\text { Sikap hormat dari } \\
\text { karyawan bank. }\end{array}$ & .487 & .454 & .440 & .105 & .233 & -.061 & -.058 \\
\hline $\begin{array}{l}\text { Layanan bank yang cepat } \\
\text { dan efisien. }\end{array}$ & .049 & .693 & .048 & .083 & .093 & .014 & .061 \\
\hline $\begin{array}{l}\text { Keakuratan layanan } \\
\text { transaksi perbankan. }\end{array}$ & .389 & .620 & -.006 & -.124 & .001 & .123 & .123 \\
\hline $\begin{array}{l}\text { Kualitas customer } \\
\text { services yang baik. }\end{array}$ & .428 & .588 & .358 & -.025 & .056 & .080 & .040 \\
\hline $\begin{array}{l}\text { Ketersediaan layanan } \\
\text { Internet Banking. }\end{array}$ & -.088 & .485 & -.018 & .081 & -.103 & .483 & .170 \\
\hline Reputasi bank yang baik. & .335 & .439 & -.267 & .101 & .025 & .330 & -.035 \\
\hline $\begin{array}{l}\text { Ketersediaan dan desain } \\
\text { kartu kredit/debit. }\end{array}$ & .208 & -.008 & .701 & .185 & .125 & .113 & .326 \\
\hline $\begin{array}{l}\text { Ketersediaan Iahan } \\
\text { parkir di bank. }\end{array}$ & .202 & .135 & .674 & .028 & .232 & .341 & -.090 \\
\hline $\begin{array}{l}\text { Rekomendasi dari } \\
\text { teman. }\end{array}$ & .108 & .058 & .103 & .899 & .108 & .138 & .084 \\
\hline $\begin{array}{l}\text { Rekomendasi dari } \\
\text { saudara/keluarga. }\end{array}$ & .235 & .016 & .092 & .885 & .051 & .063 & .122 \\
\hline $\begin{array}{l}\text { Tingkat suku bunga } \\
\text { pinjaman yang rendah. }\end{array}$ & .253 & -.004 & .065 & .055 & .765 & .073 & . 179 \\
\hline $\begin{array}{l}\text { Kemudahan nasabah } \\
\text { dalam memperoleh } \\
\text { pinjaman. }\end{array}$ & .434 & .135 & .167 & .114 & .624 & .090 & -.029 \\
\hline $\begin{array}{l}\text { Kemudahan nasabah } \\
\text { dalam membuka } \\
\text { rekening baru. }\end{array}$ & .075 & .438 & .311 & .157 & .549 & .155 & .061 \\
\hline $\begin{array}{l}\text { Lokasi ATM yang mudah } \\
\text { dijangkau. }\end{array}$ & .088 & .167 & .179 & .130 & .065 & .752 & .037 \\
\hline $\begin{array}{l}\text { Lokasi bank dekat } \\
\text { dengan rumah ataupun } \\
\text { tempat kerja. }\end{array}$ & .321 & -.063 & .210 & .023 & .208 & .692 & .033 \\
\hline $\begin{array}{l}\text { Tingkat suku bunga } \\
\text { tabungan yang tinggi. }\end{array}$ & -.049 & -.066 & -.016 & -.034 & .526 & .009 & .646 \\
\hline $\begin{array}{l}\text { Biaya administrasi yang } \\
\text { ditawarkan bersaing. }\end{array}$ & .272 & .143 & .042 & .070 & .053 & .399 & .629 \\
\hline $\begin{array}{l}\text { Biaya administrasi } \\
\text { bulanan yang rendah. }\end{array}$ & .162 & .233 & .158 & .246 & .041 & -.093 & .598 \\
\hline
\end{tabular}

Sumber: SPSS Penelitian 


\section{KESIMPULAN}

Keberadaan generasi milenial dengan presentase $34,45 \%$ dari total penduduk Indonesia serta dominasinya pada ekonomi Indonesia hingga 30 tahun ke depan (Situs Kontan, 2017), menjadikan generasi milenial sebagai pasar dengan potensi yang besar dan menjanjikan bagi para pelaku industri perbankan. Penelitian ini menemukan bahwa lokasi ATM $(6,68)$ merupakan faktor pemilihan Bank terpenting bagi generasi milenial di Jabodetabek di dalam melakukan kegiatan transaksi keuangan. Namun, faktor lokasi tersebut bukanlah satu-satunya faktor penentu, dimana skor penilaian berbeda tipis dengan faktor penentu kedua, yaitu layanan bank yang cepat dan efisien $(6,67)$. Meskipun berada pada urutan ke-4, ketersediaan layanan internet banking $(6,54)$ juga menjadi faktor penentu bagi para nasabah generasi milenial dalam memilih layanan perbankan.

Generasi milenial dikatakan memiliki mobilitas yang tinggi dan kecenderungan kurang penyabar. Jika dibandingkan dengan generasi sebelumnya, generasi milenial tumbuh pada lingkungan dengan paparan teknologi sehingga mereka lebih cepat beradaptasi dengan perkembangan teknologi yang ada (Situs Kontan, 2017). Hasil dari penelitian yang menunjukan preferensi terhadap layanan digital seperti ATM, layanan bank yang cepat dan efisien, serta ketersediaan internet banking, semakin memperkuat karakteristik generasi milenial yang memiliki kecenderungan mobilitas tinggi sehingga mereka membutuhkan efisiensi baik dari segi proses maupun waktu dalam melakukan kegiatan transaksi keuangan pada perbankan.

Sementara itu, dari ke-7 kriteria baru yang terbentuk berdasarkan proses dimension reduction, kriteria nomor 2 yaitu "Kualitas layanan yang ditawarkan" menjadi kriteria yang terpenting pada pemiliham bank bagi generasi milenial di Jabodetabek dalam melakukan transaksi keuangan. Hal ini sejalan dengan temuan penelitian sebelumnya yang dilakukan oleh Sadiq et.al (2014) di Malaysia, bahwa kriteria layanan menjadi kriteria yang terpenting. Namun, layanan bank yang cepat dan efisien sebagai faktor yang paling menentukan dalam temuan penelitian Sadiq et.al (2014), menjadi faktor penentu ke-2 dalam penelitian ini. Secara berurutan "Kemudahan dalam membuka rekening baru", "Biaya administrasi yang rendah", "Sikap hormat dari karyawan Bank", dan "Lokasi ATM yang mudah dijangkau" sebagai penentu ke-2 hingga ke-5 dalam penelitian Sadiq et.al (2014).

Terdapat perbedaan hasil temuan antara kedua penelitian, yang dapat disebabkan oleh beberapa hal, antara lain : (1) perbedaan objek penelitian, dimana penelitian ini berfokus pada generasi milenial, namun tidak demikian halnya dengan penelitian dari Sadiq et.al (2014); (2) perbedaan kondisi geografis antara kedua Negara, baik luas kota ataupun keseluruhan Negara; (3) perbedaan budaya serta paparan akan informasi, dan lain sebagainya. Hal ini lah yang dapat menyebabkan terdapat perbedaan antara hasil temuan penelitian ini dengan penelitian Sadiq et.al (2014) maupun dengan penelitianpenelitian sebelumnya, dimana generasi milenial di Jabodetabek memiliki tingkat prioritas yang berbeda akan kebutuhan layanan perbankan dibandingkan dengan generasi maupun wilayah-wilayah lainnya. 


\section{Saran Studi Lanjutan}

Penelitian dimaksudkan untuk memberikan pandangan dan informasi bagi bank yang ingin menyasar generasi milenial sebagai target konsumen yang potensial. Oleh karena itu, peneliti menyarankan kepada setiap bank yang mulai berfokus kepada generasi milenial untuk memperhatikan ketersediaan mesin ATM di setiap tempat strategis, sebab kemudahan dalam perbankan menjadi hal yang utama bagi generasi milenial. Dikutip dari Situs Marketeers (2017), kecepatan, kepraktisan, dan fleksibilitas menjadi ciri khas dari generasi milenial, sehingga kemudahan dan kecepatan layanan perbankan menjadi sesuatu yang dianggap penting oleh generasi milenial.

Bagi bank yang sudah memiliki jaringan ATM luas dapat memperluas jaringan ATM-nya karena hal tersebut akan semakin memudahkan generasi milenial dalam melakukan transaksi perbankan. Sementara, bagi bank yang belum memiliki jaringan ATM dapat mulai menjalin kerjasama dengan bank yang sudah memiliki jaringan ATM luas dalam hal ATM sharing. Sehingga dengan semakin banyak akses terhadap mesin ATM, diharapkan kecenderungan konsumen dari generasi milenial dapat meningkat.

Selain itu, peneliti juga turut memberikan saran bagi penelitian selanjutnya. Keterbatasan waktu penelitian menjadikan analisis yang dapat dilakukan hanya mencapai analisis faktor. Dalam penelitian lanjutan, dapat diteliti secara lebih lanjut korelasi antar faktor maupun korelasi antara faktor kriteria dengan faktor demografi responden. Serta, penelitian dapat mencakup kelompok yang lebih luas seperti perbandingan antara hasil dari responden generasi milenial $(Y)$ dan generasi $X$, ataupun membagi responden berdasarkan karakteristik lain seperti latar belakang pendidikan, pekerjaan, maupun status perkawinan. Juga dapat diteliti lebih lanjut mengapa kriteria utama pemilihan bank di Indonesia berbeda dengan negara lain terutama Malaysia yang menjadi acuan dalam penelitian ini.

\section{DAFTAR PUSTAKA}

Almossawi M. (2001), "Bank selection criteria employed by college students in Bahrain: an empirical analysis", International Journal of Bank Marketing, Vol. 19 Issue 3: 115-125 Aregbeyen, O. (2011),"The Determinants of Bank Selection Choices by Customers: Recent and Extensive Evidence from Nigeria", International Journal of Business and Social Science Vol. 2, No. 22: 276-288

Blankson C.,Cheng J.M.,dan Spears N. (2007), "Determinants of banks selection in USA, Taiwan, and Ghana", International Journal of Bank Marketing Vol.25, No.7: 469-489 Coetzee J., Zyl H., dan Tait M. (2012), "Selection criteria in the South African retail banking sector", African Journal of Business Management Vol. 6, No. 41: 10558-10567

Cooper R. (2012), The Millennial Generation: Research Review, National Chamber Foundation, Washington

Dauda, Y.A. dan Akingbade, W.A. (2011), "Technology innovation and Nigeria banks performance: The assessment of employee's and customer's responses", American Journal of Social and Management Sciences Vol.2, No. 3: 329-340

Field, A. (2005), Discovering Statistics Using IBM SPSS Statistics $2^{\text {nd }}$ Edition, Sage, London Howe N. dan Strauss W. (2003), Millennials Go To College, LifeCourse Associates, Virginia 
Katircioglu S.T., Tumer M., dan Kilinc C. (2011), "Banking selection criteria in the banking industry: An empirical investigation from customers in Romania cities", African Journal of Business Management Vol. 5, No. 14: 5551-5558

Monroe, A.M. dan Manrai, A.K. (2007)."A field study of customers' switching behavior for bank services", Journal of Retailing and Consumer Services, No.14:208-215

Musiime dan Ramadhan M.(2011), "Internet Banking, Consumer Adoption, and Consumer Satisfaction", African Journal of Marketing Management Vol.3, No.10:261269

Oblinger D. (2003),"Understanding The New Students", EDUCAUSE Review July-August 2003, hal. 37-47

Rao A.S. dan Sharma R.K. (2010), "Bank Selection Criteria Employed by MBA Students in Delhi: An Empirical Analysis", Journal of Business Studies Quarterly Vol. 1, No. 2: 56-69

Sadiq M., Khan S., dan Khan M. (2014), "Bank Selection Criteria: a Study in Malaysia", Actual Problem of Economics 7, No. 157: 429-435

Sayani H. dan Miniaoui H. (2013), "Determinants of bank selection in the United Arab Emirates", International Journal of Bank Marketing Vol. 31, No.3: 206-208

Situs Bisnis Indonesia, http://finansial.bisnis.com/read/20160513/5/546030/perbankandan-generasi-milenial (13 Mei 2016)

Situs CNN Indonesia, https://www.cnnindonesia.com/ekonomi/20160819114219-78152414/jumlah-wirausahawan-ri-bertambah-4-juta-orang-dalam-10-tahun/, (31 Juli 2017)

Situs Kontan, http://m.kontan.co.id/news_analisis/perbankan-dan-generasi-millennial-1 (28 Agustus 2017)

Situs Marketeers, http://marketeers.com/enam-senjata-merangkul-generasi-millennial/, (2 Agustus 2017)

Srivatsa H.S. dan Srinivasan R. (2008), "New Age Youth Banking Behavior An Explorative Study in the Indian Banking Sector", Journal of Services Research Vol 8, No. 2 (October 2008 - March 2009): 53-71

Statistikian, https://www.statistikian.com/2014/03/analisis-faktor-dengan-spss.html, (31 Juli 2017)

Statistikian, https://www.statistikian.com/2014/03/asumsi-analisis-faktor-denganspss.html, (31 Juli 2017)

Statistikian, https://www.statistikian.com/2014/03/interprestasi-analisis-faktor-denganspss.html, (31 Juli 2017)

Undang-Undang Republik Indonesia Nomor 10 Tahun 1998 Tentang Perubahan atas Undang-Undang Nomor 7 Tahun 1992 Tentang Perbankan. Jakarta: 1998 


\section{Lampiran 1}

Daftar Wawancara Awal dengan Responden

Pertanyaan: Apakah yang menjadi pertimbangan saudara dalam memilih sebuah bank sebagai partner dalam melakukan transaksi perbankan?

Interviewer: Anindia Indah

Quote dari interviewee:

1. Interviewee: Pria 28 tahun.

"Jumlah ATM ya. Biaya admin juga, free kalau ambil uang di ATM. Jangan sampe ada charge fee dan lain-lainnya."

2. Interviewee: Wanita 25 tahun.

"Biaya adminnya kecil, mudah transaksi m-banking, sama ATM-nya juga banyak."

3. Interviewee: Wanita 25 tahun.

"ATM-nya mudah ditemuin. Kayak Bank B**, ada dimana-mana ATM-nya."

4. Interviewee: Pria 34 tahun.

"Penting yang ATMnya banyak. Biaya juga jangan yang mahal-mahal ya, kalau bisa gratis malah."

5. Interviewee: Pria 26 tahun.

"Gue pasti milih yang punya ATM banyak dan ada fasilitas internet bankingnya, soalnya sibuk dan harus keep in touch sama bank setiap saat."

\section{Interviewer: Martinus Rosadi Nugroho}

Quote dari interviewee:

1. Interviewee: Wanita 24 tahun

"Saya rasa yang menjadi alasan saya memilih bank adalah jaringan ATM yang banyak, kalau tidak bisa repot nanti."

2. Interviewee: Wanita 22 tahun

"Kalau milih bank, gue liat dari namanya, pasti pilih yang uda terkenal, kalau yang namanya baru denger walau bunganya tinggi tetep ga yakin."

3. Interviewee: Wanita 25 tahun

"Pastinya pilih yang sudah banyak customer-nya, soalnya berasa aman aja gitu."

\section{Interviewee: Pria 26 tahun}

"Yang pasti yang terpercaya dan sudah punya nama baik, juga ATM yang banyak. Itu aja sih."

5. Interviewee: Pria 30 tahun

"Nomor satu sih ATMnya banyak dan bisa internet banking, soalnya kita ga pernah tau kapan butuh, kan? Sisanya? Harusnya ga jauh beda ya antara bank yang satu dengan yang lainnya."

\section{Interviewer: Elias Sugita Handoyo}

Quote dari interviewee:

1. Interviewee: Wanita 24 tahun

"Yang penting yang ATMnya banyak dan ga repot urus administrasi dan segala urusan lainnya."

2. Interviewee: Wanita 22 tahun 
"Kalo gue lebih prefer sama bank yang ga cape antrinya, terkadang urusan bank paling buang waktu dalam sehari."

3. Interviewee: Wanita 26 tahun

"Karena gue mobile orangnya, gue pasti cari bank yang punya banyak kantor cabang dan ATM dimana-mana, bank yang begitu pasti bank gede kan, jadi berasa aman juga."

4. Interviewee: Pria 28 tahun

"Karena gue punya bisnis, buat bisnis gue sih harus bank yang udah punya banyak nasabah ya, soalnya biar gampang aja pembayaran ke supplier atau dari buyer."

5. Interviewee: Pria 26 tahun

"Dari dulu sih keluarga selalu pake Bank $B^{* *}$, jadi gue ngikut aja lah biar ga ribet, hehehe."

\section{Interviewer: Ivan Angga Kusuma}

Quote dari interviewee:

1. Interviewee: Wanita 26 tahun

"ATM lah hahaha Bank B** tuh ATMnya banyak jadi enak."

2. Interviewee: Pria 30 tahun

"Gue pribadi lebih prefer sama bank yang punya ATM banyak dan cabangnya dimanamana."

3. Interviewee: Pria 27 tahun

"Saya sih selalu pakai 2 bank besar $\left(\mathrm{M}^{* * * * * *}\right.$ dan $\left.\mathrm{B}^{* *}\right)$ soalnya dua-duanya punya nama yang baik dan aman, tapi emang kecil sih bunga tabungannya."

4. Interviewee: Pria 28 tahun

"Yang ATMnya banyak lah, udah paling harus itu."

5. Interviewee: Wanita 26 tahun

"Kalo bank gue mau yang pasti-pasti aja, tau sendiri lah bank sejuta umat, ga berani nabung di bank yang abal-abal walau bunganya tinggi, hehehe." 